\title{
Un an de "séminaire expérimental de technologie". (1982-1983) École des Hautes Études en Sciences
} Sociales

\section{François Sigaut}

\section{(2) OpenEdition}

Journals

Édition électronique

URL : https://journals.openedition.org/tc/1015

DOI : $10.4000 /$ tc. 1015

ISSN : 1952-420X

Éditeur

Éditions de l'EHESS

Édition imprimée

Date de publication : 1 juin 1984

ISSN : 0248-6016

Référence électronique

François Sigaut, « Un an de "séminaire expérimental de technologie". (1982-1983) École des Hautes Études en Sciences Sociales », Techniques \& Culture [En ligne], 3 | 1984, mis en ligne le 26 janvier 2006, consulté le 29 septembre 2022. URL : http://journals.openedition.org/tc/1015 ; DOI : https://doi.org/ $10.4000 /$ tc. 1015

Ce document a été généré automatiquement le 29 septembre 2022

Tous droits réservés 
Un an de "séminaire expérimental de technologie". (1982-1983) École des Hautes Études en Sciences Sociales

François Sigaut 